\title{
Cognitive status and referential acts in functional discourse grammar
}

\author{
L'estat cognitiu i els actes referencials \\ en la gramàtica funcional discursiva
}

\section{Daniel García Velasco}

Universidad de Oviedo. danielg@uniovi.es

Received: 12/04/2018. Accepted: 22/06/2018

\begin{abstract}
In Functional Discourse Grammar, both Ascription and Reference are characterized as actional processes and are captured at the Interpersonal Level of linguistic description. Additionally, the temporal sequencing of Discourse Acts seems relevant to establishing dependency relations among them. However, the remainder of the levels of representation in the theory contain static descriptions of linguistic structures and not of processes. In this paper, I will argue that this is the result of an inherent contradiction between FDG's characterization as a static grammar and the dynamicity of verbal interaction, which is best solved if the theory commits itself to the procedural nature of the Interpersonal Level. In order to do so, the different categories that have been identified in the literature on the cognitive status of referents should find relevance in the grammar. Elaborating upon García Velasco (2014), I will show that the temporal dimension of the text creating activity and referent accessibility, are relevant for a full account of constituent preposing in Spanish.
\end{abstract}

Keywords: Functional Discourse Grammar; reference; activation; preposing.

Resum: En gramàtica funcional discursiva (FDG, en les sigles en anglès), tant l'adscripció com la referència són qualificades com a processos accionals i es localitzen en el nivell interpersonal de la descripció lingüística. D’altra banda, la seqüenciació temporal dels actes discursius sembla rellevant a l'hora d'establir-hi relacions de dependència. Tanmateix, els altres nivells de representació d'aquesta teoria inclouen descripcions estàtiques de les estructures lingüístiques i no de processos. En aquest article, mostrarem que això és el resultat d'una contradicció inherent entre la consideració de la FDG com una gramàtica estàtica i la dinamicitat de la interacció verbal, contradicció que es resol si la teoria atribueix una naturalesa procedimental al nivell interpersonal. Per poder-ho fer, les diferents categories identificades en la bibliografia sobre l'estat cognitiu

》 García Velasco, Daniel. 2018. "Cognitive status and referential acts in functional discourse grammar”. Quaderns de Filologia: Estudis Lingüistics XXIII: 155-175. doi: 10.7203/qf.23.13525 
dels referents han de tenir un lloc destacat en la gramàtica. A partir de García Velasco (2014), mostrarem que la dimensió temporal del text, en què s'originen l'activitat i l'accessibilitat del referent, és rellevant per a una proposta global de l'anteposició de constituents en espanyol.

Paraules clau: gramàtica funcional discursiva; referència; activació; anteposició. 


\section{Introduction: FDG and verbal interaction ${ }^{1}$}

Functional Discourse Grammar (henceforth FDG) is presented in Hengeveld \& Mackenzie (2008) as a typologically-based theory of language structure which is organized into four parallel linguistic levels. Each one of those levels corresponds to the main areas of grammatical analysis as indicated in (1):

$\begin{array}{ll}\text { Pragmatics } & \rightarrow \text { Interpersonal Level } \\ \text { Semantics } & \rightarrow \text { Representational Level } \\ \text { Morphosyntax } & \rightarrow \text { Morphosyntactic Level } \\ \text { Phonology } & \rightarrow \text { Phonological Level }\end{array}$

One of the main properties of this architecture of grammar is that each level is autonomous and self-contained in the sense that each one deals with its own type of linguistic information and is not sensitive to the workings and internal rules of the rest. Although they can be activated in parallel, the levels do not feed one another as in derivational theories, but rather find themselves in a relation of correspondence: one unit in each level typically corresponds to another unit at the rest of the levels of analysis, although the existence of mismatches among them is acknowledged and even assumed to be expected.

FDG thus intends to capture and represent the grammatical information which is encoded in linguistic expressions. In that sense, it is not a model of language use, understood as the human ability to construct and interpret linguistic expressions, but a structural grammar based on functional principles. At the same time, however, FDG is presented as the grammar component of a wider theory of verbal interaction which includes a number of additional components assumed to be relevant in a full account of inter-human communication. The following general diagram illustrates that the Grammar Component, FDG proper, is flanked by three additional components, the Conceptual Component, the Contextual Component and the Output Component (Hengeveld \& Mackenzie, 2008: 13).

\footnotetext{
${ }^{1}$ Thanks are due to Nuria Alturo, Francis Cornish and two anonymous reviewers for helpful comments. All remaining errors are my sole responsibility.
} 


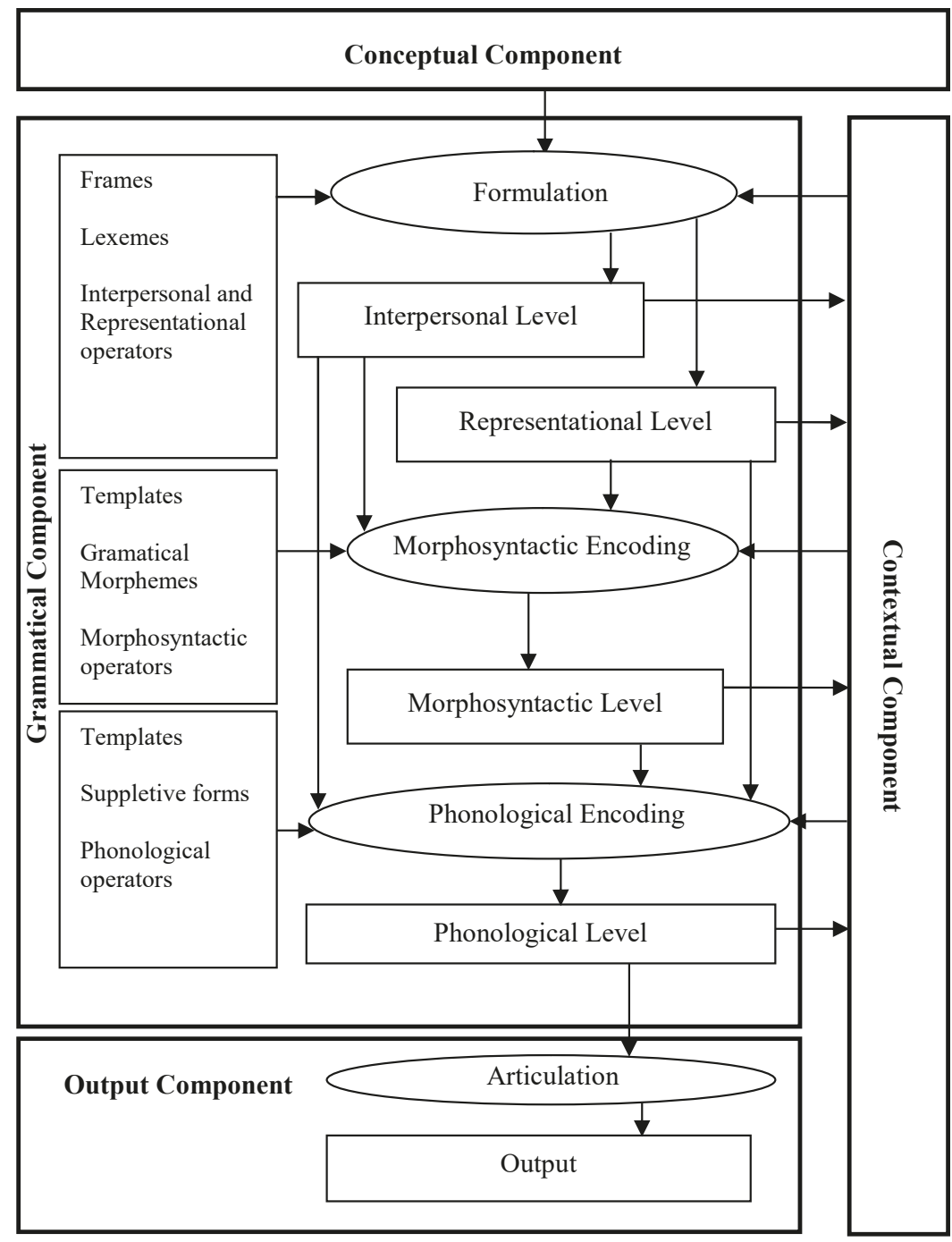

Figure 1. General layout of Functional Discourse Grammar

The rectangles in the figure indicate the different levels of representation which were mentioned earlier. These are produced by the different processes, as represented by ovals. The ovals include the op- 
erations of formulation and encoding within the grammar component. Formulation is the process by means of which pragmatic and semantic representations are produced, whereas encoding is the process by which morphosyntactic and phonological structural representations are created. The boxes on the left of the figure contain the primitives which are employed by the different operations.

As also mentioned earlier, the Grammar Component is flanked by three additional components. The Contextual Component represents the speech situation and includes both linguistic and non-linguistic perceptual information or, in current terms, discoursal and situational information (Hengeveld \& Mackenzie, 2014). The Conceptual Component is responsible for the creation of a communicative intention which will be translated through the process of Formulation into the relevant representations at the Interpersonal and Representational Levels. Finally, the Output Component is responsible for the actual execution of a linguistic expression through the operation of articulation. Note that this articulation may be of different kinds (written, signed or spoken), depending on the medium of expression chosen.

One can detect an initial and inherent tension between FDG's static approach to grammar and the necessary dynamism of language use and verbal interaction. This has posed a number of problems in the development of the model. First, some scholars initially saw FDG as a production model (see the contributions in Mackenzie \& Gómez González, 2004). This is only understandable, since FDG gained inspiration in Levelt's (1989) psycholinguistic model of the speaker and because the theory also holds that the grammar is implemented dynamically. The theory's proponents, however, have made it clear that FDG should not be seen as a production model, and that its dynamic implementation should be seen as a reflection of the sequence of steps taken by the analyst in order to "clarify the logic of the relations among the layers, levels and components" (Mackenzie, 2014: 251). This, in Hengeveld and Mackenzie's view, should be enough to meet the standard of psychological or cognitive adequacy which was proposed by Dik (1989: 13).

The second problem is of a more practical or analytical nature. It has been argued that some linguistic processes cannot be fully understood under the static conception of the grammar proposed in FDG. For example, Keizer (2014) notes that a proper understanding of the conditions governing the active/passive alternation in English demand a 
close interaction between the Contextual Component and the grammar. Similarly, García Velasco (2014) observes the relevance of the notion of activation for an account of subject raising in English, and authors like Connolly (2007) and Cornish (2009) have argued for a closer interaction between context and grammar than is assumed in FDG.

In this contribution I will pursue this line of inquiry and suggest that certain grammatical processes can only be fully understood if reference is made to the wider theory of verbal interaction of which FDG is the grammatical component. In particular, I will show that the activation status of referents is relevant to understanding the properties of constituent preposing in Spanish. The paper is organised as follows. In the next section I will lay out the main aspects of the Interpersonal Level in FDG that will be relevant in the ensuing discussion. Section 3 will be devoted to introducing aspects of the cognitive accessibility of referents. In section 4 the basic properties of preposed Topics and Foci in Spanish will be presented. Finally, in section 5, I will present my conclusions.

\section{The Interpersonal Level in FDG}

The Interpersonal Level (IL) is defined by Hengeveld \& Mackenzie (2008: 46) as the "level that deals with all the formal aspects of a linguistic unit that reflect its role in the interaction between the Speaker and the Addressee". In consonance with FDG's general strategy, only those communicative choices that find systematic reflection in the grammar are represented at this level. Consider the following exchange:

\section{(Father to son)}

Will you answer me now?

On the basis of the social relations among the two participants, it might be reasonable to interpret the utterance in (2) as an order rather than as a question. However, the expression is formally an interrogative structure with the properties typically associated therewith (i.e. auxiliary inversion or rising intonation). The fact that this expression can be felicitously used as a command is something that must be explained with reference to the Contextual Component and Pragmatic Theory (e.g. Grice 1975), but which will not lead to a reinterpretation of that structure as presenting an imperative illocution. 


\subsection{Acts and subacts}

The central unit of analysis in FDG is the Discourse Act, which is defined as "the smallest identifiable units of communicative behaviour" (Kroon, 1997: 20). It is important to stress that Discourse Acts do not correspond to a particular structural unit, as fully communicative utterances may consist of fragments of different sorts or incomplete sentences. Discourse Acts contain Referential and Ascriptive Subacts. FDG characterizes ascription and reference as actional processes. By carrying out a number of Subacts of Ascription and Reference speakers are said to evoke a Communicated Content for their addressee to reconstruct in the interpretive process (Hengeveld \& Mackenzie, 2008: 107). Subacts of reference serve to evoke an entity, whereas subacts of ascription are employed to evoke properties.

This actional view of the IL and reference and ascription is, however, somehow exceptional within the general characterization of FDG as a pattern model. Note that the remainder of the levels of representation in the theory (the Representational Level, the Morphosyntactic Level and the Phonological Level) contain static descriptions of linguistic patterns and units, and not of linguistic actions. Additionally, the IL is sensitive to the chronological organization of the communicative process. Hengeveld \& Mackenzie (2008: 47) note that "at the layers of the Move and the Discourse Act the hierarchy crucially also represents the sequence of time course of the actions, which is essential to the realization of the Speaker's strategy". In the other levels, and also within Discourse Acts at the IL, it is only hierarchical and scope relations that are relevant among the various units of analysis. This difference is particularly relevant, for if the ordering of Acts at the IL is dependent upon the speaker's communicative strategy, it would seem there is no reason why other strategic decisions that are taken at the Conceptual Component may not be reflected in the grammar. In particular, I am referring to the cognitive status of referents, whose degree of saliency or prominence is related to the chronological unfolding of the interaction and is crucial to an understanding of the assignment of pragmatic functions and the analysis of information structure in $\mathrm{FDG}^{2}$.

\footnotetext{
${ }^{2}$ An anonymous reviewer has pointed out to me that if the actional nature of the IL is taken as an anomaly, a full commitment to its procedural nature would serve to accen-
} 


\subsection{Information structure in FDG}

Subacts of Ascription and Reference may carry Pragmatic Functions, which in FDG are said to pertain to the following three dimensions:

(3) Focus (vs. background)

Topic (vs. comment)

Contrast (vs. overlap)

It is usually the first of these dimensions (i.e. Focus, Topic and Contrast) which finds grammatical manifestation in languages. It is also relevant to note that these dimensions are not complementary, so that a given subact may carry, for example, both Topic and Focus function, as in the following presentative statement:

(4) There is [a new boy in town $]_{\text {TOPFOC }}$

The assignment of Focus pragmatic function reflects the "Speaker's strategic selection of new information" and the function "is assigned only in those cases in which this is linguistically relevant" (Hengeveld \& Mackenzie, 2008: 89). Thus, in the following Thetic sentence the whole expression would receive Focus function, which correlates with specific prosodic properties:

$$
[\text { A train arrived }]_{\mathrm{FOC}}
$$

Topic function, in turn, is assigned to those constituents which signal how the "Communicated Content relates to the gradually constructed record in the Contextual Component" (Hengeveld \& Mackenzie, 2008: 92). Thus, the example in (4) not only introduces new focal information, but also a referent which is likely to be the subject matter of the subsequent discourse. Note additionally that FDG establishes a relevant difference between Topic and Orientation function. The former is assigned within a Discourse Act, but the latter is assigned to a Dis-

tuate that difference with the rest of levels. This is obviously true, but I do not see the actional nature of the IL as a problem, but as a natural consequence of its intermediate position between context, cognition and grammar, which makes it less amenable to being treated as a purely structural level. 
course Act which serves a subsidiary function to a second one. In the literature these are usually called left-detached or hanging topics and are typically intonationally set off from the rest of the utterance, as in the following Spanish example:

$$
\begin{array}{lllll}
\text { Juan }_{[\mathrm{OR}]}, & \text { no } & \text { sé } & \text { nada de } & \text { él } \\
\text { Juan } & \text { not } & \text { know.1SG } & \text { nothing of } & \text { him } \\
\text { 'John, I don't know anything about him' } & &
\end{array}
$$

Finally, Contrast function "signals the Speaker's desire to bring out the particular differences between two or more Communicated Contents or between a Communicated Content and contextually available information" (Hengeveld \& Mackenzie, 2008: 96). Although contrast is usually subsumed under Focus, Hengeveld and Mackenzie argue that it is an independent function as evidenced by the fact that it can be combined with the Topic and Focus functions. Thus, in the following sentence:

(7) It was the zoo that they went to, not the museum

Focus is combined with Contrast by means of a cleft-sentence.

Now, it would seem natural to expect that the assignment of Topic, Focus and Contrast functions is governed by properties as described in the Contextual and Conceptual components. The way in which the relation between context and grammar is understood in FDG is explained in Hengeveld \& Mackenzie (2014). In that contribution, the authors take a minimalistic approach to the type and amount of information that can be present in the Contextual Component. This information may be of two basic types: Situational and Discoursal. Discoursal information is relevant for processes of anaphoric and cataphoric reference, which entails that the Contextual Component should store information on the units that have been introduced in the discourse (or create an address for those that should be introduced later in the case of cataphoric processes). The authors argue that this sets "a clear basis for distinguishing between Given information (stored in the Contextual Component) and New information (which enters the system in the Grammatical Component)" (Hengeveld \& Mackenzie, 2014: 207). Additionally, the Contextual Component stores situational information which pertains to the physical setting in which the interaction takes place and the speech 
situation. This may also be relevant for pragmatic function assignment, as the authors indicate (Hengeveld \& Mackenzie, 2014: 210):

The perceivability of an entity in the physical world at the Representational Stratum within the Contextual Component may, for instance, lead to the selection of this entity as the Topic of a Discourse Act at the Interpersonal Level within the Grammatical Component.

However, in line with the structural approach to grammar that FDG endorses, the theory has concentrated on the formal impact of pragmatic functions on the grammar of languages, but not on the cognitive processes that lead to their assignment to particular subacts, in spite of the recognition of its relevance in the quotations above. The reason may well be that these cognitive statuses lead on most occasions to probabilistic choices only. The FDG approach to the relation between context and grammar thus reflects the inherent tension between the dynamicity of language interaction and the static approach to grammar that was mentioned earlier. On the one hand, Hengeveld and Mackenzie assume that aspects of the context may be relevant in the assignment of pragmatic functions, but FDG basically pays attention to how these are encoded in languages and what frames are relevant for a typologically adequate description of information structure in languages.

As mentioned earlier, however, it has been claimed that the analysis of a number of grammatical processes can only be fully satisfactory if reference is made to additional properties of the Contextual Component. Additionally, the distinctive properties of the IL with respect to the rest of levels in FDG seem to suggest that rather than a strict structural representation of pragmatic properties, the IL also encodes procedural information deriving from the strategic communicative choices made by speakers before formulation. If that is the case, there is no reason why FDG could not pay more attention to the accessibility of referents as a way to understanding the pragmatic structuring of linguistic expressions. I turn to this issue in the following section.

\section{The cognitive status of referents}

The dynamicity of language use implies that the assignment of pragmatic functions is necessarily dependent upon the speech participant's interpretation of the accessibility of referents as the discourse develops. 
Consequently, a well-established research tradition has concentrated on the relation between the cognitive status of referents and its impact on grammatical and syntactic form (see among others Chafe, 1994; Gundel et al., 1993; Lambrecht, 1994; Prince, 1981).

Gundel \& Fretheim (2002) establish a twofold distinction in the study of information structure: referential givenness and relational givenness. The first one "involves a relation between a linguistic expression and a corresponding non-linguistic entity in the speaker/hearer's mind, the discourse (model), or some real or possible world" (2002: $3)$. Relational givenness "involves a partition of the semantic-conceptual representation of a sentence into two complementary parts...". Gundel \& Fretheim (2002: 5) note that the two dimensions are 'logically independent'; whereas the latter is a property of linguistic representations, the former is not specifically linguistic.

In a similar vein, I argued in García Velasco $(2013 ; 2014)$ that pragmatic functions in the F(D)G tradition have been defined under a prominence / aboutness interpretation, and that a time / givenness dimension should be introduced which would relate to the pragmatic structuring of discourse and to a dynamic temporal articulation as opposed to the static form-oriented nature of aboutness. In that work, I argued that a given referent should be characterized as one which is 'active at this point in the conversation' (Chafe, 1994: 72), and proposed that the second time dimension should contain two sub-dimensions as indicated in (8), which includes all pragmatic functions now relevant for $\mathrm{FDG}^{3}$ :

\author{
Time dimension: givenness \\ Active (vs. inactive) \\ Shared (vs. unshared)
}

Prominence dimension: aboutness

Focus (vs. background)

Topic (vs. comment)

Contrast (vs. overlap)

FDG has concentrated on the prominence dimension only, for the reasons explained earlier. As a structural grammar, the model pays

\footnotetext{
${ }^{3}$ See García Velasco (2014) for the relevance of the shared vs. unshared dimension.
} 
attention to those aspects of the communicative situation that have a formal impact on the grammar of languages.

However, this does not mean that all other categories identified in the study of the cognitive status of referents and the time dimension do not have relevance for FDG. Consider the case of identifiability, a notion which is intimately related to that of activation. Identifiability is given operator status in FDG. Subacts of reference are marked as $\{+\mathrm{id}\}$ if the speaker assumes that the intended referent is identifiable for his/her addressee. As a consequence, FDG treats identifiability as a linguistically-relevant notion, whereas the related notion of activation is considered non-linguistic and is therefore not captured in the grammar per se. This strategy runs counter to most approaches to identifiability and activation. For example, Gundel \& Hedberg (2016: 35) (see also Gundel Hedberg \& Zacharski, 1993) note that nominal expressions "encode two kinds of information: (1) procedural information about how to mentally access a representation of the intended referent/interpretation (...); and (2) conceptual / descriptive information about the referent / interpretation." FDG includes descriptive information about referents at the Representational Level, but as argued earlier, procedural information of the kind envisaged by Gundel \& Hedberg (2016) is only partly included in the IL.

It should be noted, however, that the relative prominence of referents is treated by Hengeveld \& Mackenzie (2014) as an objective property of the contextual component. In that work, they introduce the notion of contextual saliency which is characterized as follows (2014: 210):

Contextual saliency is an observable feature of texts and situations and relies on the actual mention of an entity in a discourse or its actual perception in the situation in which a text is produced. Contextual saliency is therefore necessarily shared between interlocutors.

In their view this contrasts with the notion of activation, which they see as "highly individual" (Hengeveld \& Mackenzie, 2014: 210-211). Therefore, they conclude that "Activation state as a notion is therefore relevant within the Conceptual Component".

As I argued in García Velasco (2014), however, (see also Connolly, 2007), it is difficult to conceive of the Contextual Component as a purely objective entity. There is no objective context, as it is always mediated by the way it is perceived or understood by speakers. The communica- 
tive choices made by the speech participants rely on their interpretation of the Contextual Component through the Conceptual Component. In other words, speakers interpret the properties of the situation and base their communicative strategy on that interpretation. In that sense, it is true that activation is relevant in the Conceptual Component, and so is every communicative intention, as all of them are informed by the context. This leads, as mentioned earlier, to the sequencing of acts at the IL, to actions of ascription and reference, to the assignment of $\{+\mathrm{id}\}$ status to referents and Topic or Focus function to a given subact. The picture which thus emerges is one in which the IL encodes procedural information rather than pure grammatical choices offered by the system. The introduction of a time dimension is thus natural under an interpretation of the IL as a level in which contextually informed linguistic actions are encoded.

In previous work of mine (García Velasco, 2008; 2013) I have shown that the pragmatic functions in the time dimension are relevant for a proper understanding of phenomena such as syntactic extraction from complex noun phrases and subject raising. In the following section I will additionally show that the combination of the time and prominence dimensions with their respective pragmatic functions offers the necessary tools for an adequate treatment of as yet poorly understood properties of preposing in the Spanish language.

\section{Pragmatic preposing in Spanish}

Like many other languages, Spanish makes use of clause-initial position to place constituents with special pragmatic status ${ }^{4}$. However, the communicative burden of preposed constituents may be of different types, and this correlates with different syntactic and phonological properties.

Bosque \& Gutiérrez-Rexach (2009: 354) distinguish two types of topics in Spanish: "hanging topics" as in (9a), which serve to introduce a new topic in discourse, and which correspond to the Orientation function in FDG (cf. 6 above), and "left-detached" topics as in (9b), which provide more emphasis on an already active topic:

\footnotetext{
${ }^{4}$ For comprehensive treatments of Spanish syntax see Bosque \& Demonte (1999) and RAE \& ASALE (2009).
} 


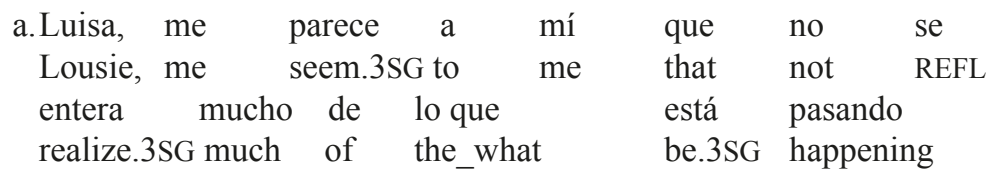
'Louise, it seems to me that she does not realize of what's going on'

b.Las lentejas, no las soporto.

The lentils not them bear.1SG

'Lentils, I can't stand them'

Left-detached topics may sometimes be found without a significant intonation break, but they typically establish a relation with a co-referential non-predicative visible or null pronoun in the clause. Indeed, unlike (9a), (9b) can be easily read without a full intonation break after the displaced noun phrase, which, presumably, would get Topic function in a FDG analysis. This means that, unlike (9a), which contains two Discourse Acts, (9b) can be analysed as containing just one Discourse Act. The simplified analysis for the ILs in both (9a) and (9b) are given in (10a) and (10b) respectively:

$$
\begin{aligned}
& \text { a. }\left(M_{I}:\left[\left(A_{I}:- \text { Luisa- }\left(A_{I}\right)\right)_{O R}\right.\right. \\
& \left.\left.\qquad\left(A_{J}:- \text { me parece a mi que...- }\left(A_{J}\right)\right)\right]\left(M_{I}\right)\right) \\
& \text { b. }\left(M_{I}:\left[\left(A_{I}:-(\text { las lentejas })_{T O P} \text { no las soporto- }\left(A_{I}\right)\right)\right]\left(M_{I}\right)\right)
\end{aligned}
$$

Consider now the following examples (RAE \& ASALE 2009: 2989)

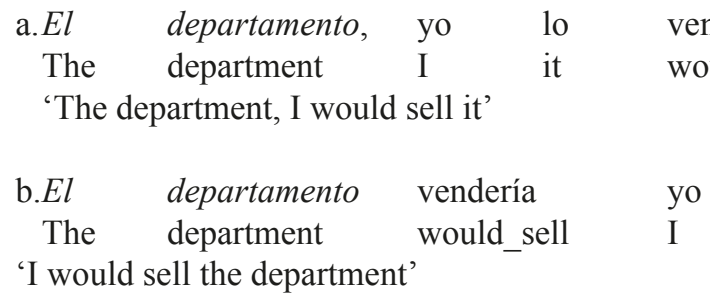

\footnotetext{
${ }^{5}$ RAE: Real Academia Española; ASALE: Asociación de Academias de la Lengua Española.
} 
In example (11a) the sequence el departamento is clearly a left-detached topic (cf. 9b). It is intonationally set off from the rest of the sentence, which also contains a pronominal element lo referring back to the detached topic. Note additionally that the pronominal subject yo occupies preverbal position. In (11b), which is truth-conditionally equivalent to (11a), the sequence el departamento now functions as a focal unit and is phonologically integrated in the clause, which does not (and cannot) present a coreferential pronominal element as in (10a). Additionally, the subject of the sentence yo is necessarily postposed. As noted by RAE \& ASALE (2009: 2989) preposed foci in Spanish are always displaced from intra-clausal positions. In FDG, this expression would be analysed as realizing just one Discourse Act, with the noun phrase el departamento bearing, presumably, Focus function:

$$
\left(M_{I}:\left[\left(A_{I}:-(e l \text { departamento })_{F O C} \text { vendería yo- }\left(A_{I}\right)\right)\right]\left(M_{I}\right)\right)
$$

In other words, at the IL, the analysis of preposed topical and focal constituents in Spanish seems to differ only in the pragmatic function assigned to the displaced units, with the concurrent morphosyntactic and phonological differences being captured at the relevant levels. It follows that in those cases in which those properties do not conclusively distinguish one construction from the other, it may be difficult to determine the pragmatic function of the displaced unit. The difficulty in distinguishing preposed topics and foci is somehow tacitly acknowledged in FDG. Thus, Hengeveld \& Mackenzie (2008: 92) argue that in the following Dutch example, demonstrative dat bears Topic function and its antecedent is located in the Contextual Component.

$\begin{array}{lllll}\text { Dat heb } & \text { ik } & \text { nooit } & \text { gezegd } \\ \text { That have } & \text { I } & \text { never } & \text { said } \\ \text { 'I never said that' } & & & \end{array}$

However, they follow Mackenzie \& Keizer (1991) in claiming that English has no Topic function "since no formal features exist in the language which justify the assumption of Topic function" (see Cornish 2004 for relevant discussion). In the following example, then, clause initial that is necessarily accented and therefore expresses Contrast function (Hengeveld \& Mackenzie, 2008: 93): 
Now, if clause-initial position may be used for the placement of both topical and focal or contrastive units it would seem natural to find languages which exploit both possibilities. This is precisely what we find in Spanish, a language in which clause-initial position may be used for the assignment of both Topic and Focus function as shown earlier.

Hengeveld \& Mackenzie (2008: 95) themselves illustrate the assignment of Topic function to ascriptive subacts with the following Spanish example:

$\begin{array}{lll}\text { Llover } & \text { no } & \text { llueve } \\ \text { Rain } & \text { not } & \text { rain.3SG }\end{array}$

'Raining, it does not rain'

But, of course, there are plenty of examples of Topic function assignment to referential acts:

$$
\begin{array}{cll}
\text { a.El dinero } & \text { sobraba } \\
\text { The money } & \text { left_over.3SG }
\end{array}
$$

'There was too much money'

$\begin{array}{cllll}\text { b.La } & \text { televisión } & \text { no } & \text { la } & \text { veo } \\ \text { The } & \text { TV } & \text { not } & \text { it } & \text { see.1SG }\end{array}$

'I don't watch the TV'

Initially, it would seem that it is not difficult to distinguish the Topic/ Orientation function from preposed foci in Spanish. As indicated earlier (see RAE \& ASALE, 2009: 2974), Orientation and left-detached topics usually (but not always) require the presence of a coreferential element in the clause and are intentionally set off from the rest of the sentence. Preposed foci, additionally, are usually accented (as in English) and are not followed by an intonation break. However, the existence of preposed topical constituents with no clear intonation break (examples 15 and 16) and no pronominal copy (examples 15 and 16a), which are indeed treated in FDG as cases of Topic function assignment, might seem problematic: given that clause-initial position can be used for both focal and topical units, the interpretation of the displaced unit may be difficult or ambiguous at times. Thus, in the following example 
taken from RAE \& ASALE (2009: 2974) the preposed prepositional phrase de la próxima función is compatible with both a focal and topical interpretation:

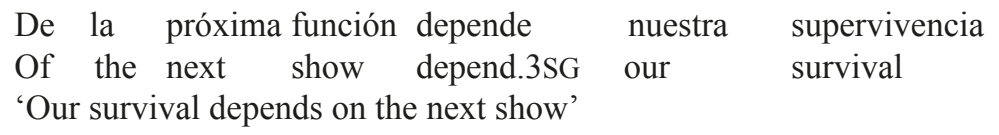

In other cases, the presence or absence of an intonation break is the only determining factor for one interpretation or the other, as in the following example (RAE \& ASALE, 2009: 2975):

$\begin{array}{lllllll}\text { En esta casa } & (,) & \text { viví } & \text { yo } & \text { diez } & \text { años } \\ \text { In this house } & & \text { lived } & \text { I } & \text { ten } & \text { years }\end{array}$

'I lived in this house ten years'

Consequently, the existence of ambiguous cases and the common properties of preposed Topics and Foci in Spanish pose the question of what makes them both acceptable in clause-initial position. Preposed focal constituents in Spanish may be of different structural types, including prepositional or adverbial phrases, quantifiers or noun phrases. As for the latter, it is interesting to observe that many of the examples of preposed referential acts provided by RAE \& ASALE contain anaphoric expressions (RAE \& ASALE, 2009: 2987):

$\begin{array}{clllll}\text { a. Eso mismo pensaba hacer } & \text { yo } & \text { esta } & \text { tarde } \\ \text { That same thought do } & \text { I } & \text { this } & \text { evening }\end{array}$

'That I was thinking to do this evening'

b. Estas cosas tenía yo en la cabeza
Those things had I in the head
'Those things I had in my mind'

It is well-known that the use of demonstratives correlates with a relevant degree of activation status of their referents (Gundel et al., 1993; Cornish, this issue). In particular, the examples in (19) are only felicitous if the antecedent has been introduced in the immediate previous discourse or is perceivable in the current setting. In other words, many of these preposed foci serve a discourse-deictic function (strict-anadeix- 
is in Cornish's terms) and contribute to discourse cohesion by keeping a referent active. This means that clause-initial position seems a natural place for those constituents with a relevant activation state. This state may be compatible with a focal or topical interpretation, leading to the assignment of one or the other function and the manifestation of the corresponding grammatical properties. Interestingly, left-detached topics seem to serve the same general strategy of keeping a referent active, as indicated earlier.

However, FDG as currently conceived offers no way of explaining both the differences and similarities in information status between preposed topics and foci with reference to the activation state of the displaced units. The introduction of Activation in the time dimension as proposed earlier can easily solve this problem if both focal and topical units may optionally get an Active pragmatic function in the relevant cases. According to Lambrecht (1994: 115-116), the activation states of referents should be seen as preconditions for topic and focus function. Thus, the same activation state may be reflected in topic or focal status. This is illustrated with the following contrast in Italian and French (emphasis as indicated in original):

a. IO PAGO / MOI je PAYE.

'I'll PAY.'

b. Pago IO / C'est MOI qui paye.

'I'll pay.'

The pronominal expressions in (20) have the same activation state in both examples, but receive focus function only in (20b). This expression is likely to be uttered in a context in which it is presupposed that someone has to pay something and two or more people intend to do so. Therefore, the sentences differ only in the pragmatic function of the pronominal expressions but their referents are necessarily active since they are speech participants themselves.

Thus ambiguous cases such as (17) and (18) above may be explained on the basis of the model proposed. The ambiguity arises because the displaced unit is active in both cases, and serves a similar discourse function, in spite of their differences in informative value. But this analysis is only possible if Activation is included in the grammar as an ad- 
ditional pragmatic function along the time dimension, which relates to the dynamic construction of discourse.

\section{Conclusions}

In this paper, I have shown that the Interpersonal Level in FDG is somehow exceptional in the theory's architecture in that it is the only one that encodes linguistic actions and is sensitive to the chronological sequence of the communicative choices that speakers deploy. This is understandable as this level occupies an intermediate position between the Conceptual Component (which in my view includes the speakers' mental representation of the Contextual Component) and linguistic meaning and form. It should also be noted that the procedural flavour of the Interpersonal Level in FDG was already noticed in the first years of the model (see Mackenzie, 2004). Elaborating upon García Velasco (2014), I have also shown that the temporal dimension and the cognitive status of referents, in particular, their degree of activation status, is relevant in a full account of constituent preposing in Spanish.

Obviously, not all preposed Foci in this language contain anaphoric expressions as in the examples in (13). In this contribution I have only concentrated on referential units, so that an examination of the properties of different types of constituents in clause-initial position is an interesting exercise for future research. In all, it has become evident that in order to understand the relevance of clause-initial position in Spanish, it is necessary to go beyond the limits of the grammatical properties manifested in individual sentences and pay attention to the role and status of referents in larger stretches of discourse.

\section{References}

Bosque, Ignacio \& Demonte, Violeta (coord.). 1999. Gramática descriptiva de la lengua española. Madrid: Espasa.

Bosque, Ignacio \& Gutiérrez-Rexach, Javier. 2009. Fundamentos de sintaxis formal. Madrid: Akal.

Chafe, Wallace. 1994. Discourse, Consciousness and Time. Chicago: The University of Chicago Press.

Connolly, John H. 2007. Context in Functional Discourse Grammar. Alfa 51: 11-33. 
Cornish, Francis. 2004. Focus of attention in discourse. In Mackenzie, J. L. \& Gómez-González, M. A. (ed.) A New Architecture for Functional Grammar. Berlin: Mouton de Gruyter, 117-150.

Cornish, Francis. 2009. Text and discourse as context: Discourse anaphora and the FDG Contextual Component. Web Papers in Functional Discourse Grammar 82: 97-115.

Cornish, Francis. This issue. Anadeixis and the signalling of discourse structure.

Dik, Simon C. 1989. The Theory of Functional Grammar. Part 1. The Structure of the Clause. Dordrecht: Foris.

García Velasco, Daniel. 2008. Functional Discourse Grammar and extraction from (complex) Noun Phrases. In Rijkhoff, Jan \& García Velasco, Daniel (ed.) The Noun Phrase in Functional Discourse Grammar. Berlin: Mouton de Gruyter, 321-363.

García Velasco, Daniel. 2013. Raising in Functional Discourse Grammar. In Mackenzie, J. Lachlan \& Olbertz, Hella (ed.) Casebook in Functional Discourse Grammar. Amsterdam: John Benjamins, 249-276.

García Velasco, Daniel. 2014. Activation and the relation between context and grammar. Pragmatics 24: 297-316. doi: https://doi.org/10.1075/ prag.24.2.06gar

Grice, H. Paul. 1975. Logic and conversation. In Cole, P. \& Morgan, J. L. (ed.) Syntax and Semantics 3. Speech Acts. New York: Academic Press, 4158.

Gundel, Jeanette K. \& Fretheim, Thornstein. 2002. Information Structure. In Verschueren, J.; Östman, J.-O.; Blommaert, J. \& Bulcaen, C. (ed.) Handbook of Pragmatics Online. Amsterdam: Benjamins, 1-18.

Gundel, Jeanette K.; Hedberg, Nancy \& Zacharski, Ron. 1993. Cognitive status and the form of referring expressions in discourse. Language 69: 274-307.

Gundel, Jeanette K. \& Hedberg, Nancy. 2016. Reference and cognitive status: Scalar inferences and typology. In Fernandez-Vest, M. M. Jocelyne \& Van Valin, Robert D. (ed.) Information Structuring of Spoken Language from a Cross-Linguistic Perspective. Berlin: Mouton de Gruyter, 33-53.

Hengeveld, Kees \& Mackenzie, J. Lachlan. 2008. Functional Discourse Grammar. Oxford: Oxford University Press.

Hengeveld, Kees \& Mackenzie, J. Lachlan. 2014. Grammar and context in Functional Discourse Grammar. Pragmatics 24: 203-227. doi: https:// doi.org/10.1075/prag.24.2.02hen

Keizer, Evelien. 2014. Context and cognition in Functional Discourse Grammar: What, where and why? Pragmatics 24: 399-423. doi: https://doi. org/10.1075/prag.24.2.10kei 
Kroon, C. 1997. Discourse markers, discourse structure and Functional Grammar. In Connolly, John H.; Vismans, Roel M.; Butler, Christopher S. \& Gatward, Richard A. (ed.) Discourse and Pragmatics in Functional Grammar. Berlin: Mouton de Gruyter, 17-32.

Lambrecht, Knud. 1994. Information Structure and Sentence Form. Cambridge: Cambridge University Press.

Levelt, Willem J. 1989. Speaking. From Intention to Articulation. Cambridge (MA): The MIT Press.

Mackenzie, J. Lachlan. 2004. Functional Discourse Grammar and language production. In Mackenzie, J. L. \& Gómez-González, M. A. (ed.) A New Architecture for Functional Grammar. Berlin: Mouton de Gruyter, 179195.

Mackenzie, J. Lachlan. 2014. The Contextual Component in a dialogic FDG. Pragmatics 24: 249-273. doi: https://doi.org/10.1075/prag.24.2.04mac

Mackenzie, J. Lachlan \& Gómez-González, M. A. (ed.) 2004. A New Architecture for Functional Grammar. Berlin: Mouton de Gruyter.

Mackenzie, J. Lachlan \& Keizer, Evelien. 1991. On assigning pragmatic functions in English. Pragmatics 1: 169-215.

Prince, Ellen F. 1981. Toward a taxonomy of given-new information. In Cole, P. (ed.) Radical Pragmatics. New York: Academic Press, 223-256.

Real Academia Española y Asociación de Academias de la Lengua Española. 2009. Nueva Gramática de la lengua española. Madrid: Espasa. 
